\title{
Defensins from the tick lxodes scapularis are effective against phytopathogenic fungi and the human bacterial pathogen Listeria grayi
}

Miray Tonk ${ }^{1,2}$, Alejandro Cabezas-Cruz ${ }^{3,4}$, James J Valdés ${ }^{1}$, Ryan OM Rego ${ }^{1}$, Tereza Chrudimská ${ }^{1,2}$, Martin Strnad ${ }^{1,2}$, Radek Šíma', Lesley Bell-Sakyi ${ }^{5}$, Zdeněk Franta ${ }^{6}$, Andreas Vilcinskas ${ }^{6,7}$, Libor Grubhoffer ${ }^{1,2^{*}}$

and Mohammad Rahnamaeian ${ }^{6,7^{*}}$

\begin{abstract}
Background: /xodes scapularis is the most common tick species in North America and a vector of important pathogens that cause diseases in humans and animals including Lyme disease, anaplasmosis and babesiosis. Tick defensins have been identified as a new source of antimicrobial agents with putative medical applications due to their wide-ranging antimicrobial activities. Two multigene families of defensins were previously reported in $I$. scapularis. The objective of the present study was to characterise the potential antimicrobial activity of two defensins from I. scapularis with emphasis on human pathogenic bacterial strains and important phytopathogenic fungi.

Methods: Scapularisin-3 and Scapularisin-6 mature peptides were chemically synthesised. In vitro antimicrobial assays were performed to test the activity of these two defensins against species of different bacterial genera including Gram-positive bacteria Staphylococcus aureus, Staphylococcus epidermidis, and Listeria spp. as well as Gram-negative bacteria Escherichia coli, Pseudomonas aeruginosa along with two plant-pathogenic fungi from the genus Fusarium. In addition, the tissue-specific expression patterns of Scapularisin-3 and Scapularisin-6 in I. scapularis midgut, salivary glands and embryo-derived cell lines were determined using PCR. Finally, tertiary structures of the two defensins were predicted and structural analyses were conducted.

Results: Scapularisin-6 efficiently killed L. grayi, and both Scapularisin-3 and Scapularisin-6 caused strong inhibition ( $\mathrm{C}_{50}$ value: $\sim 1 \mu \mathrm{M}$ ) of the germination of plant-pathogenic fungi Fusarium culmorum and Fusarium graminearum. Scapularisin-6 gene expression was observed in I. scapularis salivary glands and midgut. However, Scapularisin-3 gene expression was only detected in the salivary glands. Transcripts from the two defensins were not found in the $I$. scapularis tick cell lines ISE6 and ISE18.

Conclusion: Our results have two main implications. Firstly, the anti-Listeria and antifungal activities of Scapularisin-3 and Scapularisin-6 suggest that these peptides may be useful for (i) treatment of antibiotic-resistant L. grayi in humans and (ii) plant protection. Secondly, the antimicrobial properties of the two defensins described in this study may pave the way for further studies regarding pathogen invasion and innate immunity in I. scapularis.
\end{abstract}

Keywords: Antimicrobial peptide, Defensin, Listeria grayi, Fusarium spp, Ixodes scapularis, Tick cell line

\footnotetext{
*Correspondence: liborex@paru.cas.cz; mohammad.rahnamaeian@agrar.unigiessen.de

'Biology Centre of the AS CR, Institute of Parasitology, Branišovská 31, 37005

České Budějovice, Czech Republic

${ }^{6}$ Fraunhofer Institute for Molecular Biology and Applied Ecology, Department

of Bioresources, Winchester Strasse, D-35394 Giessen, Germany

Full list of author information is available at the end of the article
} 


\section{Background}

The blacklegged tick Ixodes scapularis is an important vector of pathogens such as Borrelia burgdorferi, Babesia microti and Anaplasma phagocytophilum that cause important diseases in humans and animals. In response to pathogen infection, ticks develop a complex system of defence that involves elements of the innate immune system [1]. One of the most important features of the tick immune response is the rapid synthesis and release of antimicrobial peptides (AMPs) [2]. Amongst the naturally-occurring AMPs, the small defensin peptides are the most studied and widely-characterised class of antimicrobial peptides from several tick species [2-4]. Mature defensins are cyclic peptides possessing a pattern of six paired cysteine residues in their primary structure with three or four disulphide bridges, forming a conserved cysteine-stabilised $\alpha$-helix and $\beta$-sheet $(\mathrm{CS} \alpha \beta)$ motif crucial for their antimicrobial activity [1,5]. Most defensins are cationic; however some anionic defensins have been reported [6-8]. Two multigene families of defensins, Scapularisin and Scasin, were reported in $I$. scapularis, both of them presenting high phylogenetic and structural diversity [5]. A functional domain of one I. scapularis defensin, Scapularisin-20, was functionally characterised and found to show activity against Gramnegative (Gram-) and Gram-positive (Gram+) bacteria [5]. However, tick defensins have a wide spectrum of antimicrobial activity, including antibacterial, antifungal, antiprotozoal and antiviral activities; thus defensins are excellent candidates to tackle the increasing problem of drug resistance seen in microbes and fungi [9-11].

Listeria spp. are small Gram+, non spore-forming, facultative anaerobic bacteria widely distributed in the environment [12-14]. The Listeria genus consists of 10 species: Listeria monocytogenes, Listeria ivanovii, Listeria fleischmannii, Listeria innocua, Listeria welshimeri, Listeria seeligeri, Listeria martini, Listeria rocourtiae, Listeria weihenstephanensis and Listeria grayi [15-20]. In addition to the major human pathogen L. monocytogenes [13]. Occasional human infections have been reported with L. ivanovii [21-23], L. grayi [24], L. seeligeri and L. innocua $[25,26]$. There is also some evidence suggesting that strains of L. innocua are occasionally pathogenic to deer, cattle and sheep [27]. Listeria species have also been isolated from a variety of food products, including commercially prepared ready-to-eat foods and from food-processing environments [14]. Recently, a human stem cell transplant recipient was found to be infected with a vancomycin-resistant strain of L. grayi [28]. Fusarium culmorum is a ubiquitous soil-borne fungus and plant pathogen capable of causing ear and root rot in different small-grain cereals, in particular wheat and barley. Contamination with $F$. culmorum causes reduction in plant growth and significant yield and quality losses.
In addition, the fusarium infection is concomitant with mycotoxin contamination [29,30]. Fusarium graminearum is another very important causative agent of Fusarium head blight (FHB) of small grain cereals like wheat and barley and of ear rot in maize [31] and other cereals worldwide [32,33].

Herein, we examined and characterised the activity, where present, of synthetic Scapularisin-3 and Scapularisin6 mature peptides against the Gram + bacteria L. grayi, other Listeria spp., Staphylococcus aureus and Staphylococcus epidermidis, the Gram- bacteria Escherichia coli and Pseudomonas aeruginosa, and the fungal pathogens $F$. culmorum and F. graminearum. Additionally, we determined the transcriptional expression pattern of these defensins in the salivary glands and midgut of $I$. scapularis ticks and in two I. scapularis embryo-derived cell lines, as well as carrying out a structural analysis of the two defensins.

\section{Methods}

\section{Defensin sequences and preparation of synthetic Scapularisins}

Using publicly available sequence data [5], 38 amino acids of the mature peptides of each of Scapularisin-3 (Genbank accession number: EEC13914) and Scapularisin-6 (Genbank accession number: EEC08935) were chemically synthesised with $\approx 95 \%$ purity (Peptide 2.0, USA). Lyophilised peptides were stored at $-20^{\circ} \mathrm{C}$ until use.

\section{Antibacterial assays}

Concentrations of the peptides ranging from 0.03 to $250 \mu \mathrm{M}$ were used to test antibacterial activity and MIC (minimum inhibitory concentration) of the peptides against Gram + bacterial species including L. fleishmannii (DSM 24998), L. grayi (DSM 20601), L. marthii (DSM 23813), L. innocua (DSM 20649), L. welshimeri (DSM 20650), L. seeligeri (DSM 20751), L. rocourtiae (DSM 22097), S. aureus (DSM 2569) and S. epidermidis (DSM 3269) as well as the Gram- bacteria E. coli (D31) and P. aeruginosa (DSM 50071). The assays were performed in either Brain Heart Infusion Broth (BHIB) medium in case of Listeria spp. or Tryptic Soy Broth (TSB) (Roth, Karlsruhe, Germany) for others, in 384-well plates (Griener Bio One, Frickenhausen, Germany). Bacteria in the mid-logarithmic phase were used for growth inhibition assays. The initial optical density (OD), at $600 \mathrm{~nm}$, for Listeria spp. was set to 0.01 and for the rest of the bacteria to 0.001 to ensure full contact of each bacterial cell with defensins added to the suspensions. Changes in OD were monitored at 20 min intervals over a $24 \mathrm{~h}$ period using an EonTM Microplate Spectrophotometer (BioTel Instruments, VT, USA). For each assay, a medium-only control culture was included. Antimicrobial activity of the peptides was tested against all bacteria and the assays were repeated for confirmation. 
(All microorganism strains were available at the Fraunhofer Institute for Molecular Biology and Applied Ecology, Department of Bioresources).

\section{Antifungal assays}

Fungicidal activities of synthetic peptides were determined using an inhibition assay reported previously [34]. F. culmorum and F. graminearum strain 8/1 [35] were cultured in the dark on Nirenberg Synthetic Nutrient Agar (SNA) medium at $18^{\circ} \mathrm{C}$ for $1-2$ weeks [36]. Briefly, F. culmorum and F. graminearum were incubated with different concentrations of the peptides from $0.1 \mu \mathrm{M}$ to $20 \mu \mathrm{M}$ at room temperature for $24 \mathrm{~h}$ under humid conditions. Spore germination and growth were monitored using an inverted microscope Motic AE21 (Motic, China). The $\mathrm{IC}_{50}$ values were recorded when only $50 \%$ of the spores germinated in the solution.

\section{Ticks and tick organ collection}

I. scapularis ticks were provided by the Institute of Parasitology, Academy of Sciences of the Czech Republic. Uninfected ticks were reared for several generations in the animal facilities of the Institute and fed on adult guinea pigs that were raised to be free of infection under the hygiene regulations of the Central Commission for the Protection of Animals ( $\$ 21$, section 3e, the Animal Protection Law of the Czech Republic No. 246/1992 sb., ethics approval number 137/2008). Ticks were fed on adult guinea pigs and ten partially engorged ( 6 days post attachment) female I. scapularis were collected for further analysis. For salivary glands and midgut collection, the ticks were affixed to the bottom of a Petri dish with wax, submerged in PBS, incised along the dorso-lateral margin and the dorsal integument was removed under a binocular microscope. The organs were excised, washed in PBS to remove excess blood, transferred into RNAlater ${ }^{\circ}$ solution (Ambion, USA) and kept at $-80^{\circ} \mathrm{C}$ for later use (protocol modified from [37]).

\section{Cell culture}

The I. scapularis embryo-derived cell lines ISE6 and ISE18 [38,39] were maintained at $28^{\circ} \mathrm{C}$ in $\mathrm{L}-15$ (Leibovitz) medium (Life technologies, USA) supplemented with $20 \%$ heat-inactivated foetal bovine serum, $10 \%$ tryptose phosphate broth, $2 \mathrm{mM}$ L-glutamine, $100 \mathrm{IU} / \mathrm{ml}$ penicillin, $100 \mu \mathrm{g} / \mathrm{ml}$ streptomycin and $0.25 \mu \mathrm{g} / \mathrm{ml}$ amphotericin B. Medium was changed weekly by removal and replacement of $3 / 4$ of the medium volume and subcultures were carried out when required [40].

\section{RNA isolation and CDNA synthesis}

The salivary glands and midguts for RNA isolation were homogenised by passing through a $0.9 \mathrm{~mm}$ needle (20 gauge) fitted to a syringe. From the ISE6 and ISE18 in vitro cultures, $5 \times 10^{6}$ cells were harvested. Total RNA isolation from salivary glands, midgut, ISE6 and ISE18 was performed using the NucleoSpin ${ }^{\circ}$ RNA II kit (Macherey Nagel, Germany). A total of $60 \mu \mathrm{L}$ RNase-free $\mathrm{H}_{2} \mathrm{O}$ was used for elution. The RNA concentration and purity were determined by measuring the optical density at both 260 and $280 \mathrm{~nm}$ using a spectrophotometer NanoDrop ${ }^{\circ}$ ND1000 (Peqlab, Erlangen, Germany). After determination of RNA concentration and integrity, the samples were diluted using RNase-free $\mathrm{H}_{2} \mathrm{O}$, dispensed into aliquots of $10 \mu \mathrm{l}$ each and frozen at $-80^{\circ} \mathrm{C}$ until being used in a cDNA synthesis reaction. Single-strand cDNA was prepared using $1 \mu \mathrm{g}$ of total RNA with random primers $(0.2 \mu \mathrm{g}$ per reaction) using the Transcriptor High Fidelity cDNA Synthesis Kit (Roche, Germany) according to the manufacturer's protocol.

\section{PCR}

The oligonucleotide primers (Generi Biotech, Czech Republic) used for detecting expression of genes from different tissues and cells are shown in Table 1. Beta-actin ( $\beta$-actin) was used as a control. Two independent PCR reactions were performed for each gene. For each PCR amplification, $1 \mu \mathrm{l}$ of cDNA was used as the template in a $20 \mu \mathrm{l}$ reaction mixture containing 20 pmol of each primer and $2 \times$ PCR Master Mix (Promega, USA). The reactions were conducted in an Eppendorf Mastercycler Personal (Eppendorf, Germany) with the following parameters: $5 \mathrm{~min}$ at $96^{\circ} \mathrm{C}$, followed by 35 cycles at $96^{\circ} \mathrm{C}$ for $30 \mathrm{~s}, 55^{\circ} \mathrm{C}$ for $30 \mathrm{~s}$ and $72^{\circ} \mathrm{C}$ for $1 \mathrm{~min}$. The final extension step was at $72^{\circ} \mathrm{C}$ for $10 \mathrm{~min}$. PCR products were visualised by agarose gel electrophoresis.

\section{Tertiary protein modeling}

Predicted tertiary models of the mature peptides were generated using the Phyre2 server [41]. The predicted models were then refined via minimisation and the hydrogen-bond network optimised using the Schrodinger's Maestro Protein Preparation Wizard [42]. The electrostatic potentials for each structure were calculated using the implemented Poisson-Boltzmann equation in the Maestro software.

\section{Table 1 Primers used in this study}

\begin{tabular}{ll}
\hline Primer & Sequence \\
\hline Sca3-F & 5'-ATGAAGGTCGTTGGAATTGCTCTT-3' \\
Sca3-R & 5'-TTATTTCTGGTAACAGGTGCAAGTTC-3' \\
Sca6-F & 5'-ATGAGGGTCATTGCTGTTACCTTGA-3' \\
Sca6-R & 5'-TTAGTTGTGGTAGCATGTGCACGTC-3' \\
Actin-F & 5'-ATGTGTGACGACGAGGTTGCCGC-3' \\
Actin-R & 5'- GTACAGCGACAGCACGGCCTGG -3' \\
\hline
\end{tabular}




\section{Results}

\section{Scapularisin-6 possesses inhibitory activity against L. grayi}

The antimicrobial activities of both defensins were evaluated against the Gram + bacteria S. aureus, S. epidermidis and seven Listeria spp., and the Gram- bacteria E. coli and P. aeruginosa. Of these, only L. grayi was susceptible to increasing concentrations of Scapularisin-6, being totally inhibited in the presence of $120 \mu \mathrm{M}$ Scapularisin-6 (Figure 1). No activity against any of the bacterial species used in the antimicrobial assays was detected for Scapularisin-3, tested at a range of concentrations up to $250 \mu \mathrm{M}$. Antimicrobial assays using a combination of Scapularisin-3 and 6 were performed, however no additive effect was observed (data not shown).

\section{Scapularisin-3 and Scapularisin- 6 are potent antifungal agents}

Additionally, we assessed the antifungal activity of Scapularisin-3 and Scapularisin-6 using two major phytopathogenic fungi, F. culmorum and F. graminearum. Both Scapularisin-3 and Scapularisin-6 showed high levels of antifungal activity. Scapularisin-3 totally inhibited germination of $F$. culmorum and $F$. graminearum spores at concentrations of, 0.5 and $1 \mu \mathrm{M}$, respectively (Table 2; Figure 2). In case of Scapularisin-6, maximum activity was recorded at $1 \mu \mathrm{M}$ and $2 \mu \mathrm{M}$ against $F$. culmorum and F. graminearum (Table 2; Figure 2) respectively.

\section{Biochemical properties and tertiary structure of Scapularisin-3 and Scapularisin-6}

The primary structures of Scapularisin-3 and Scapularisin6 are shown in Figure 3A. The deduced amino acid sequences of the prodefensins are 70 amino acids for Scapularisin-3 and 74 amino acids for Scapularisin-6. As

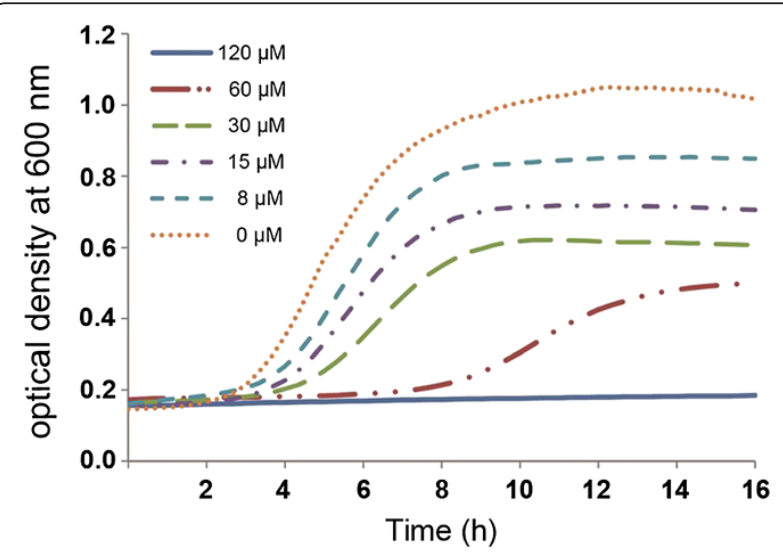

Figure 1 Antimicrobial activity of Scapularisin- 6 against $L$. grayi. The figure represents bacterial growth curves at different concentrations of Scapularisin-6 peptide. Total growth inhibition was observed at $120 \mu \mathrm{M}$ of peptide concentration (blue line). The experiment was repeated with the same results.
Table 2 Antifungal activity of synthetic I. scapularis defensins

\begin{tabular}{lcc}
\hline & $\mathbf{I C}_{\mathbf{5 0}}$ value $(\boldsymbol{\mu M})$ \\
\hline Peptide & F. culmorum & F. graminearum \\
Scapularisin-3 & 0.5 & 1 \\
Scapularisin-6 & 1 & 2 \\
\hline
\end{tabular}

$\mathrm{IC}_{50}$ : Half maximal inhibitory concentration.

indicated in Figure 3A, the two prodefensins contain a furin motif, indicating putative enzymatic cleavage in vivo by the enzyme Furin. After cleavage, both mature proteins contain 38 amino acid residues. The mature peptides of Scapularisin-3 and Scapularisin-6 have predicted molecular weights of $4.3 \mathrm{kDa}$ and $4.1 \mathrm{kDa}$, respectively. The tertiary structures of the I. scapularis defensins are similar and are conserved when compared to the NMR structure of the antibacterial defensin DEF-AAA from Anopheles gambiae ([43]; Figure 3B). The defensins depicted in Figure 3, however, are missing the archetypal disulphide bond that links both termini, and deletions in the $\alpha$-core motif and insertions in the $\gamma$-core motifs are shorter. The overall backbone deviation does not exceed $3.2 \AA$ and the deviation between the two I. scapularis defensins are $<1 \AA$ (Figure 3C). In Figure 3B we also show that the cationic electrostatic surface of Scapularisin-3 (pI 9.4) and Scapularisin-6 (pI 8.7) is mainly basic (blue); however, Scapularisin-6 possesses slightly more acidic residues (red). These acidic surfaces are within the $\alpha$-core motif with the residues Thr10 and Ser13 in Scapularisin-3 substituted by Ala10 and Arg13 in Scapularisin-6 (GxCHxHC), indicated by the yellow arrowhead in Figure 3B.

\section{Scapularisin-3 and Scapularisin-6 present different expression patterns}

In order to determine the expression profiles of Scapularisin-3 and Scapularisin-6 in I. scapularis salivary gland, midgut and embryo-derived cell lines, RNA was extracted from these tissues and PCR amplification of transcripts of the Scapularisin-3, Scapularisin-6 and $\beta$-actin genes was performed. Scapularisin- 6 gene expression was observed in both salivary glands and midgut (Figure 4). However, Scapularisin-3 gene expression was only observed in the salivary glands. No transcripts from either defensin were amplified from the ISE6 or ISE18 tick cell lines (Figure 4).

\section{Discussion}

I. scapularis presents one of the largest defensin families reported so far in ticks. This tick species presents two phylogenetically divergent groups of defensins named Scapularisin and Scasin, with 25 and 21 members, respectively [5]. Of the 25 Scapularisins, only the $\gamma$-core of Scapularisin-20 has been functionally characterised so 

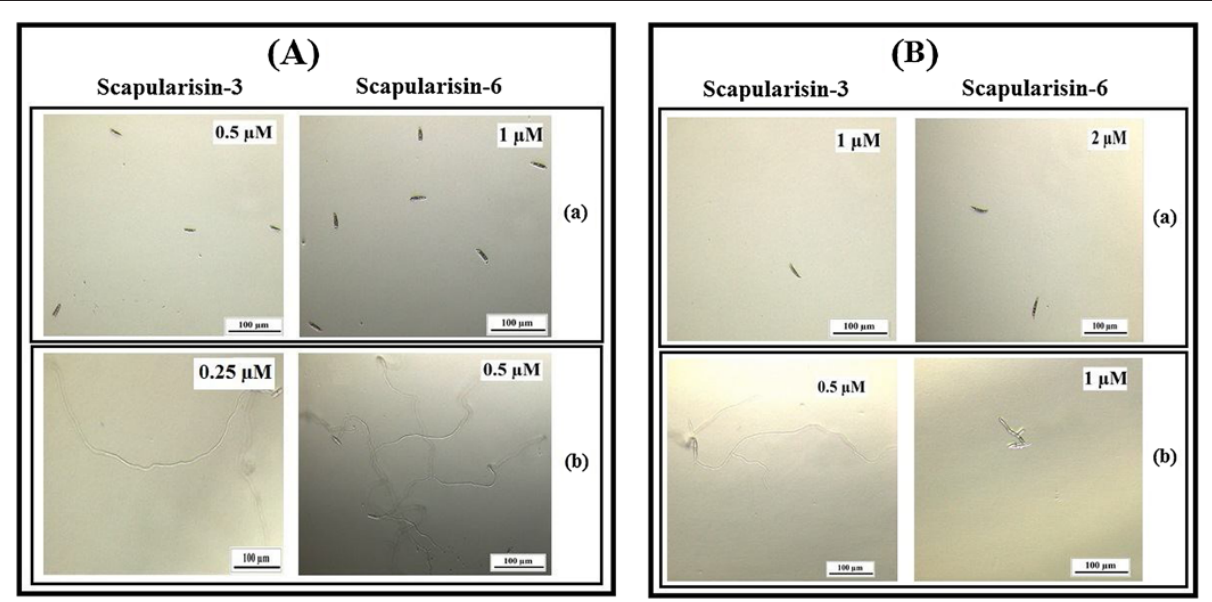

Figure 2 Antifungal activity of Scapularisin-3 and Scapularisin-6 against Fusarium spp. Images show (a) inhibition of spore germination and (b) spore germination (presence of hyphae) at different concentrations of Scapularisin-3 and Scapularisin-6. Pictures of the respective fungal cultures were taken after 24 hours of incubation of F. culmorum (A) and F. germinearum (B) with the peptides.

far, and it shows antimicrobial activity against Gram - and Gram + bacteria [5]. Thus a gap exists regarding the spectrum of biological functions of I. scapularis defensins. Our results expand the knowledge on the antimicrobial spectrum of I. scapularis defensins since we showed that Scapularisins are effective not only against the bacterium L. grayi, but also against fungi $F$. culmorum and F. graminearum. In addition, this is the first study showing the activity of tick defensins against the above microorganisms.

The antibacterial activity of tick defensins has been reported to be mainly directed against Gram + bacteria, but some isoforms were reported to also have activity against Gram- bacteria [44-49]. However, the activity of the defensins tested in this study seems to be rather specific, mainly against fungi. The $\gamma$-core of Scapularisin-3 and Scapularisin-6 differ in 5 amino acids (out of 14 that form the $\gamma$-core) with that of Scapularisin-20 (data not shown). Considering the importance of the $\gamma$-core in the biological function of defensins, sequence divergence may explain the differences in functions among these three defensins. In addition, in the present study we tested the activity of the mature Scapularisin-3 and Scapularisin-6 while Wang and Zhu, 2011 [5] tested only the

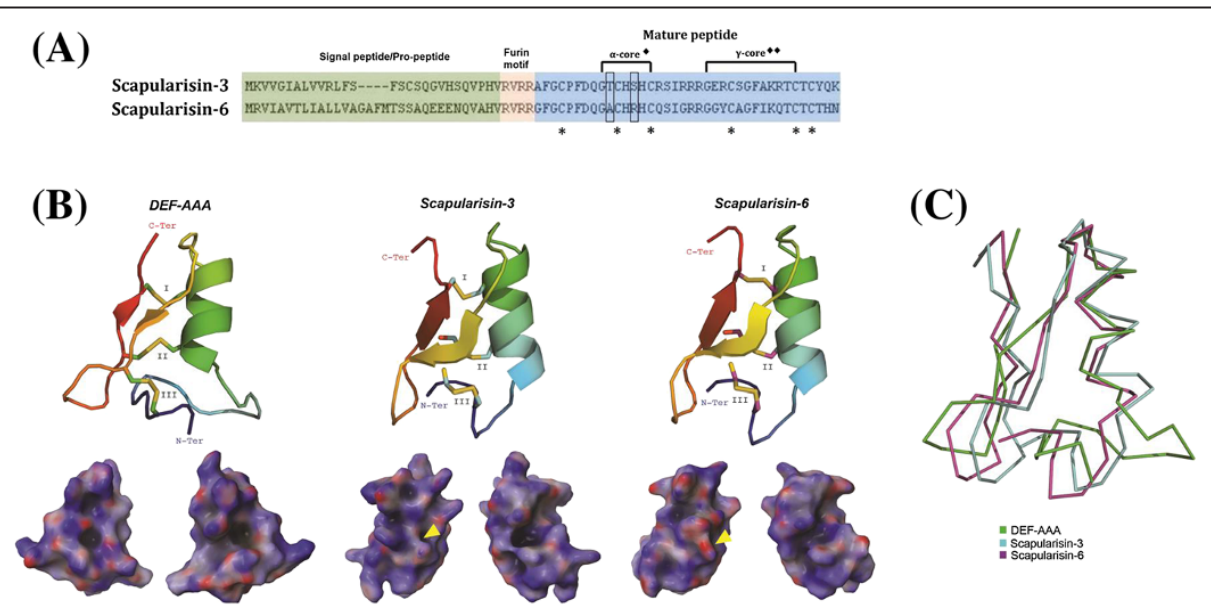

Figure 3 Biochemical properties and tertiary structure of Scapularisin-3 and Scapularisin-6. (A) Alignment of the primary structure of the defensins: represents Scapularisin-3 and Scapularisin-6. Deduced amino acid sequences of prodefensins are 70 and 74 amino acids for Scapularisin-3 and Scapularisin-6, respectively. After cleavage, both mature proteins contain 38 amino acid residues (mature peptides). Within the $a$-core motif residues Thr10 and Ser13 in Scapularisin-3 are substituted with Ala10 and Arg13 in Scapularisin-6, enclosed in rectangles, and the six conserved cysteine residues are indicated by stars $([57]$, [5]). (B) Tertiary structure of defensin peptides. Panel B displays the NMR defensin structure from A. gambiae (DEF-AAA; PDB: 2NY8) and the two predicted tertiary structures of Scapularisin-3 (GenBank: EEC13914) and Scapularisin-6 (GenBank: EEC08935). The tertiary structures depict the conserved disulphide bridges (roman numerals), loops, $\beta$-sheets, and the $a$-helix. All structures are coloured from the $\mathrm{N}$-terminus (blue) to the $\mathrm{C}$-terminus (red). Below are the respective electrostatic potentials for each structure in $180^{\circ}$ turns (blue = positive; red $=$ negative; white $=$ neutral). (C) The protein backbone alignment in Panel $\mathbf{C}$ depicts each structure colour coded as indicated. 


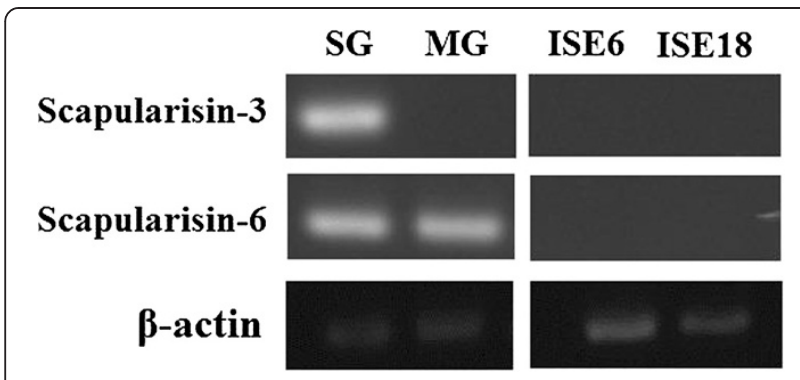

Figure 4 Expression of Scapularisin-3 and Scapularisin- 6 in tick tissues and cell lines. The expression pattern determined by PCR and visualised by agarose gel electrophoresis of Scapularisin-3 and Scapularisin-6 in I. scapularis salivary glands (SG), midgut (MG) and embryo-derived tick cell lines ISE6 and ISE18 is shown. Both defensins were expressed in SG. Scapularisin- 6 was expressed in MG and neither of the two defensins was expressed by embryo-derived tick cells (ISE6 and ISE18) in vitro. ( $\beta$-actin was used as a positive control).

activity of the $\gamma$-core of Scapularisin-20. The activity of mature peptides compared to the activity of $\gamma$-core may differ. The fact that Scapularisin-6 showed specific antibacterial activity against $L$. grayi gains relevance considering that a growing number of Listeria strains resistant to antimicrobial compounds and particularly to antibiotics have been reported [28,50]. Thus, the identification of anti-listerial agents has become extremely important [51].

Remarkably, Scapularisin-3 and Scapularisin-6 exhibit high antifungal activities (with very low MIC of $\sim 1 \mu \mathrm{M}$ ) against highly destructive plant pathogenic fungi, i.e., Fusarium spp. The ascomycete $F$. graminearum has major economic impact in the agriculture industry [52]. In general, the control of Fusarium spp has become challenging; for example azole, one of the available fungicides, is only moderately effective against F. graminearum [53]. Thus, new control methods are needed. Some results suggest that defensins in general are effective against Fusarium spp. The expression of radish defensin in trangenic wheat confers resistance to F. graminearum [54]. In addition, defensins isolated from the venom of the snake Bothrops jararaca [55], from the plant Nicotiana alata [56] and from mice [57] have been shown to be effective against some species of Fusarium. In our study, the IC50 against F. culmorum and F. graminearum of both Scapularisin-3 and Scapularisin-6 are considerably low $(1 \mu \mathrm{M})$. When compared to Scapularisin-6, Scapularisin-3 caused growth inhibition of fungi at a lower concentration. However, our results suggest that Scapularisin-3 is more potent than Scapularisin-6 as antifungal agent. Scapularisin-3 has many substitutions to Arg when compared to Scapularisin-6. A recent study found that cationic residues (such as Arg) within the $\alpha$-core and $\gamma$-core motifs found in plant defensins are important in antifungal activity against F. graminearum [58]. Further studies should be carried out in order to clarify the mechanistic actions of I. scapularis defensins against fungi of the genus Fusarium and their potential for plant protection [59].

Here we demonstrated that Scapularisin-3 and Scapularisin-6 are transcribed differentially in I. scapularis salivary glands and midgut. This is in agreement with the expression patterns of defensins identified recently in I. ricinus, some of which seem to be tissue-specific and others ubiquitous [8]. Scapularisin-6 was previously shown to be expressed in the midgut, haemocytes, and fat-body of I. scapularis [60]. Our results confirm that it is expressed in the midgut and in addition we provide a new site of expression, the salivary glands. Hynes and colleagues mentioned that another gene expressed in the salivary glands from I. scapularis (AAV80792) has one leucine "L" at position 17 while Scapularisin-6 has one phenylalanine " $F$ " and they speculated that "L" and not "F" was the salivary gland isoform. Our results show that isoform " $\mathrm{F}$ " is expressed in all the organs.

In contrast to the novel defensins from $I$. ricinus that were all constitutively expressed in the I. ricinus embryoderived cell line IRE/CTVM19, except for DefMT5 [8], expression of the two I. scapularis defensins Scapularisin-3 and Scapularisin-6 was not detected in either of the embryo-derived tick cell lines ISE6 and ISE18. Although tick cell lines are generally quite heterogeneous, having been derived from multiple tissue types $[39,40]$, they do not necessarily represent cells from the full complement of tick organs present in the starting material. ISE6 and ISE18 are relatively homogeneous lines compared to the I. ricinus line IRE/CTVM19 (authors' unpublished observations). It may be that the cell types expressing Scapularisin-3 and Scapularisin-6 in whole tick salivary glands and midgut are not present in the I. scapularis cell lines, while some of the cell types expressing the $I$. ricinus defensins are present in the more heterogeneous cell line derived from the latter species. Moreover, the pattern of defensin expression may differ between cells of tick embryos that have never experienced bacterial challenge or even a bloodmeal, or partially-fed adult female ticks removed from a vertebrate host. Further studies involving in vitro microbial challenge of these and additional $I$. scapularis and $I$. ricinus cell lines [40] are needed to fully elucidate the expression patterns of defensins in embryo-derived cells.

\section{Conclusion}

Two defensins from I. scapularis were functionally characterised and they showed activity against fungi and the Gram + bacterium L. grayi. Both Scapularisin-3 and Scapularisin-6 were highly effective against $F$. graminearum and $F$. culmorum suggesting their promise for plant protection purposes. In addition, Scapularisin- 6 has activity against the bacterium L. grayi. Our results confirm the antimicrobial activity of tick defensins and the potential of these defensins to be used as drugs against important agricultural and medical pathogens. 


\section{Abbreviations}

AMP: Antimicrobial peptide; aa: Amino acid(s); kDa: Kilodalton(s); MIC: Minimum inhibitory concentration; $I_{50}$ : Half maximal inhibitory concentration.

\section{Competing interests}

The authors declare that they have no competing interests.

\section{Authors' contributions}

MT designed the study, performed the functional analysis of synthetic peptides, interpreted the results, performed in silico analysis, wrote the manuscript and contributed to editing of the manuscript. ACC contributed to the overall design, supervision of the study to drafting the manuscript and editing of the manuscript. JJV performed tertiary structure predictions, refinement and analyses. TC designed primers and obtained the sequences. ROMR contributed to designing the molecular analyses, analysis of results and editing of the manuscript. MS performed RNA extraction, CDNA synthesis and PCR for the expression analysis. RŠ provided CDNA samples from tick organs. LBS provided tick cell lines and corrected English in the manuscript. ZF contributed to designing the molecular analyses. AV contributed to resource supply. LG contributed to design of the study and resource supply. MR designed, supervised the study and wrote the manuscript. All authors critically revised the manuscript and have given final approval of the version to be published.

\section{Acknowledgments}

We are grateful to Ulrike Munderloh, University of Minnesota, and the Tick Cell Biobank, The Pirbright Institute for providing ISE6 and ISE18 cell lines and Martin Palus for maintaining them.

Miray Tonk is a Marie Curie Early Stage Researcher supported by the POSTICK ITN (Post-graduate training network for capacity building to control ticks and tick-borne diseases) within the FP7- PEOPLE - ITN programme (EU Grant No. 238511). This project was partially supported by the Grant Agency of the Czech Republic (GACR P302/11/1901) and with institutional support RVO: 60077344 from Biology Centre, Institute of Parasitology as well as grant ANTIGONE (EU-7FP; 278976). James J. Valdés was sponsored by project CZ.1.07/2.3.00/30.0032, co-financed by the European Social Fund and the state budget of the Czech Republic. Radek Šima was supported by the Grant 13-12816P (GA CR). Mohammad Rahnamaeian and Andreas Vilcinskas acknowledge the Ministry for Science and Art of the State of Hesse (Germany) for funding the LOEWE Center of Insect Biotechnology and Bioresources. Zdeněk Franta was supported by Alexander von Humboldt Research Fellowship for Postdoctoral Researchers.

\section{Author details}

${ }^{1}$ Biology Centre of the AS CR, Institute of Parasitology, Branišovská 31, 37005 České Budějovice, Czech Republic. ${ }^{2}$ Faculty of Science, University of South Bohemia, Branišovská 31, 37005 České Budějovice, Czech Republic. ${ }^{3}$ SaBio. Instituto de Investigación en Recursos Cinegéticos IREC, CSIC-UCLM-JCCM Ronda de Toledo s/n, 13005 Ciudad Real, Spain. ${ }^{4}$ Center for Infection and Immunity of Lille (CIIL), INSERM U1019 - CNRS UMR 8204, Université Lille Nord de France, Institut Pasteur de Lille, Lille, France. ${ }^{5}$ The Pirbright Institute, Ash Road, Pirbright, Surrey GU24 ONF, UK. ${ }^{6}$ Fraunhofer Institute for Molecular Biology and Applied Ecology, Department of Bioresources, Winchester Strasse, D-35394 Giessen, Germany. ${ }^{7}$ Institute for Phytopathology and Applied Zoology, Justus-Liebig-University of Giessen, Heinrich-Buff-Ring 26-32, D-35392 Giessen, Germany.

Received: 19 May 2014 Accepted: 21 November 2014 Published online: 03 December 2014

\section{References}

1. Hajdušek O, Šíma R, Ayllón N, Jalovecká M, Perner J, de la Fuente J, Kopacek P: Interaction of the tick immune system with transmitted pathogens. Front Cell Infec Microbio 2013, 3:26.

2. Taylor D: Innate immunity in ticks: a review. J Acarol Soc Japan 2006, 15:109-127.

3. Kopáček $P$, Hajdušek $O$, Burešová $V$, Daffre S: Tick innate immunity. Adv Exp Med Biol 2010, 708:137-162. Review.
4. Nakajima Y, van Naters-Yasui AV, Taylor D, Yamakawa M: Antimicrobial peptide defensin is involved in midgut immunity of the soft tick, Ornithodoros moubata. Insect Mol Biol 2002, 11:611-618.

5. Wang $Y$, Zhu S: The defensin gene family expansion in the tick Ixodes scapularis. Dev Comp Immunol 2011, 35:1128-1134.

6. Ganz T, Lehrer Rl: Defensins. Curr Opin Immunol 1994, 6:584-589.

7. Lai R, Lomas LO, Jonczy J, Turner PC, Ress HH: Two novel non-cationic defensin-like antimicrobial peptides from haemolymph of the female tick, Amblyomma hebraeum. Biochem J 2004, 379:681-685.

8. Tonk M, Cabezas-Cruz A, Valdés JJ, Rego ROM, Rudenko N, Golovchenko M, Bell-Sakyi L, de la Fuente J, Grubhoffer L: Identification and partial characterisation of new members of the Ixodes ricinus defensin family. Gene 2014, 540:146-152.

9. Bulet $P$, Stöcklin R, Menin L: Anti-microbial peptides: from invertebrates to vertebrates. Immunol Rev 2004, 198:169-184.

10. Kocan KM, de la Fuente J, Manzano-Roman R, Naranjo V, Hynes WL, Sonenshine DE: Silencing expression of the defensin, varisin, in male Dermacentor variabilis by RNA interference results in reduced Anaplasma marginale infections. Exp Appl Acarol 2008, 46:17-28.

11. Pasupuleti M, Schmidtchen A, Malmsten M: Antimicrobial peptides: key components of the innate immune system. Crit Rev Biotechnol 2012, 32:143-171.

12. Bajard S, Rosso L, Fardel G, Flandrois JP: The particular behaviour of Listeria monocytogenes under sub-optimal conditions. Int J Food Microbiol 1996, 29:201-211.

13. Farber JM, Peterkin PI: Listeria monocytogenes, a food-borne pathogen. Microbiol Rev 1991, 55:476-511.

14. Hage E, Mpamugo O, Ohai C, Sapkota S, Swift C, Wooldridge D, Amar CFL: Identification of six Listeria species by real-time PCR assay. Lett Appl Microbiol 2014, 58(6):535-540

15. Garrity GM, Bell JA, Lilburn TG: Taxonomic Outline of the Prokaryotes. Bergey's Manual of Systematic Bacteriology. 2. New York: Springer; 2004.

16. Liu D: Identification, subtyping and virulence determination of Listeria monocytogenes, an important foodborne pathogen. J Med Microbiol 2006, 55:645-659.

17. Graves LM, Helsel LO, Steigerwalt AG, Morey RE, Daneshvar Ml, Roof SE, Orsi RH, Fortes ED: Listeria marthii sp. nov., isolated from the natural environment, Finger Lakes National Forest. Int J Syst Evol Microbiol 2010, 60:1280-1288.

18. Leclercq A, Clermont D, Bizet C, Grimont PAD, Le Fléche-Matéos A, Roche SM, Buchrieser C, Cadet-Daniel V: Listeria rocourtiae sp. nov. Int J Syst Evol Microbiol 2010, 60:2210-2214

19. Bertsch D, Rau J, Eugster MR, Haug MC, Lawson PA, Lacroix C, Meile L: Listeria fleischmannii sp. nov., isolated from cheese. Int J Syst Evol Microbiol 2013, 63:526-532.

20. Lang HE, Neuhaus K, Scherer S: Listeria weihenstephanensis sp. nov., isolated from the water plant Lemna trisulca taken from a freshwater pond. Int J Syst Evol Microbiol 2013, 63:641-647.

21. Cummins AJ, Fielding AK, McLauchlin J: Listeria ivanovii infection in a patient with AIDS. J Infect 1994, 28:89-91.

22. Lessing MPA, Curtis GDW, Bowler ICJ: Listeria ivanovii infection. J Infect 1994, 29:230-231.

23. Guillet $C$, Join-Lambert $O$, Le Monnier A, Leclercq A, Mechai F, MamzerBruneel MF, Bielecka MK, Scortti M: Human listeriosis caused by Listeria ivanovii. Emerg Infect Dis 2010, 16:136-138.

24. Rapose A, Lick SD, Ismail N: Listeria grayi bacteremia in a heart transplant recipient. Transpl Infect Dis 2008, 10:434-436.

25. Rocourt J, Hof H, Schrettenbrunner A, Malinverni R, Bille J: Acute purulent Listeria seeligeri meningitis in an immunocompetent adult. Schweiz Med Wochenschr 1986, 116:248-251.

26. Perrin $\mathrm{M}$, Bemer M, Delamare C: Fatal case of Listeria innocua bacteremia. J Clin Microbiol 2003, 41:5308-5309.

27. Walker JK, Morgan JH, McLauchlin J, Grant KA, Shallcross JA: Listeria innocua isolated from a case of ovine meningoencephalitis. Vet Microbiol 1994, 42:245-253.

28. Salimnia H, Patel D, Lephart PR, Fairfax MR, Chandrasekar PH: Listeria grayi: vancomycin-resistant, gram-positive rod causing bacteremia in a stem celll transplant recipient. Transp Infect Dis 2010, 12:526-528.

29. Lucas S, Baștas K, Budak H: Exploring the interaction between small RNAs and $\mathrm{R}$ genes during Brachypodium response to Fusarium culmorum infection. Gene 2014, 536:254-264.

30. Scherm B, Virgilio BS, Francesca S, Giovanna P, Giovanna D, Matias P, Quirico M: Fusarium culmorum: causal agent of foot and root rot and head blight on wheat. Molec Plant Pathol 2013, 14:323-341. 
31. Bormann J, Boenisch MJ, Brückner E, Firat D, Schäfer W: The adenylyl cyclase plays a regulatory role in the morphogenetic switch from vegetative to pathogenic lifestyle of Fusarium graminearum on wheat. PLOS ONE 2014, 9:e91135.

32. Pagnussatt FA, Del Ponte EM, Garda-Buffon J, Badiale-Furlong E: Inhibition of Fusarium graminearum growth and mycotoxin production by phenolic extract from Spirulina sp. Pestic Biochem Physiol 2014, 108:21-26.

33. Ward TJ, Clear RM, Rooney AP, O'Donnell K, Gaba D, Patrick S, Starkey DE, Gilbert J, Geiser DM, Nowicki TW: An adaptive evolutionary shift in Fusarium head blight pathogen populations is driving the rapid spread of more toxigenic Fusarium graminearum in North America. Fungal Genet Biol 2008, 45:473-484.

34. Rahnamaeian M, Langen G, Imani J, Khalifa W, Altincicek B, von Wettstein D: Insect peptide metchnikowin confers on barley a selective capacity for resistance to fungal ascomycetes pathogens. J Exp Bot 2009, 60:4105-4114.

35. Miedaner T, Reinbrecht C, Schilling AG: Association among aggressiveness, fungal colonization, and mycotoxin production of 26 isolates of Fusarium graminearum in winter rye head blight. Zeitsch Pflanzenkrank Pflanzenschutz 2000, 107:124-134.

36. Rahnamaeian M, Vilcinskas A: Defense gene expression is potentiated in transgenic barley expressing antifungal peptide metchnikowin throughout powdery mildew challenge. J Plant Res 2012, 125:115-124.

37. Fogaça AC, Lorenzini DM, Kaku LM, Esteves E, Bulet P, Daffre S: Cysteine-rich antimicrobial peptides of the cattle tick Boophilus microplus: isolation, structural characterization and tissue expression profile. Dev Comp Immunol 2004, 28:191-200.

38. Kurtti TJ, Munderloh UG, Andreadis TG, Magnarelli LA, Mather TN: Tick cell culture isolation of an intracellular prokaryote from the tick Ixodes scapularis. J Invert Pathol 1996, 67:318-321.

39. Munderloh UG, Liu Y, Wang M, Chen C, Kurtti TJ: Establishment, maintenance and description of cell lines from the tick Ixodes scapularis. J Parasitol 1994, 80:533-543.

40. Bell-Sakyi L, Zweygarth E, Blouin EF, Gould EA, Jongejan F: Tick cell lines: tools for tick and tick-borne disease research. Trends Parasitol 2007 , 23:450-457.

41. Kelley LA, Sternberg MJE: Protein structure prediction on the Web: a case study using the Phyre server. Nat Protocols 2009, 4:363-371.

42. Li X, Jacobson MP, Zhu K, Zhao S, Friesner RA: Assignment of polar states for protein amino acid residues using an interaction cluster decomposition algorithm and its application to high resolution protein structure modeling. Proteins Struct Funct Bioinformatics 2007, 66:824-837.

43. Landon C, Barbault F, Legrain M, Guenneugues M, Vovelle F: Rational design of peptides active against the gram positive bacteria Staphylococcus aureus. Proteins 2008, 72:229-239.

44. Chrudimská T, Chrudimsky' T, Golovchenko M, Rudenko N, Grubhoffer L: New defensins from hard and soft ticks: similarities, differences, and phylogenetic analyses. Vet Parasitol 2010, 167:298-303

45. Saito Y, Konnai S, Yamada S, Imamura S, Nishikado H, Ito T, Onuma M, Ohashi K: Identification and characterisation of antimicrobial peptide, defensin, in the taiga tick, Ixodes persulcatus. Insect Mol Biol 2009, 18:531-539.

46. Yu D, Sheng Z, Xu X, Li J, Yang H, Liu Z, Rees HH, Lai R: A novel antimicrobial peptide from salivary glands of the hard tick, Ixodes sinensis. Peptides 2006, 27:31-35.

47. Lu X, Che Q, Lv Y, Wang M, Lu Z, Feng F, Liu J, Yu H: A novel defensin-like peptide from salivary glands of the hard tick, Haemaphysalis longicornis. Protein Sci 2010, 19:392-397.

48. Nakajima Y, van Naters-Yasui AV, Taylor D, Yamakawa M: Two isoforms of a member of the arthropod defensin family from the soft tick, Ornithodoros moubata (Acari: Argasidae). Insect Biochem Mol Biol 2001, 31:747-751.

49. Tsuji N, Battsetseg B, Boldbaatar D, Miyoshi T, Xuan X, Oliver JH Jr, Fujisaki K: Babesial vector tick defensin against Babesia sp. parasites. Infect Immun 2007, 75:3633-3640.

50. Schwaiger K, Schmied EM, Bauer J: Comparative analysis on antibiotic resistance characteristics of Listeria spp. and Enterococcus spp. isolated from laying hens and eggs in conventional and organic keeping systems in Bavaria, Germany. Zoonoses Pub HIth 2009, 57:171-180.

51. Mukherjee K, Abu Mraheil M, Silva S, Müller D, Cemic F, Hemberger J, Hain T, Vilcinskas A, Chakraborty T: Anti-Listeria activities of Galleria mellonella hemolymph proteins. App/ Env Microbiol 2011, 77:4237-4240.
52. Nielsen LK, Cook DJ, Edwards SG, Ray RV: The prevalence and impact of Fusarium head blight pathogens and mycotoxins on malting barley quality in UK. Int J Food Microbiol 2014, 28(179C):38-49.

53. Dean R, Van Kan JA, Pretorius ZA, Hammond-Kosack KE, Di Pietro A, Spanu PD, Rudd JJ, Dickman M, Kahmann R, Ellis J, Foster GD: The Top 10 fungal pathogens in molecular plant pathology. Mol Plant Pathol 2012, 13:414-430.

54. Li Z, Zhou M, Zhang Z, Ren L, Du L, Zhang B, Xu H, Xin Z: Expression of a radish defensin in transgenic wheat confers increased resistance to Fusarium graminearum and Rhizoctonia cerealis. Funct Integr Genomics 2011, 11:63-70.

55. Gomes VM, Carvalho AO, Da Cunha M, Keller MN, Bloch C Jr, Deolindo P, Alves EW: Purification and characterization of a novel peptide with antifungal activity from Bothrops jararaca venom. Toxicon 2005, 45:817-827.

56. Dracatos PM, van der Weerden NL, Carroll KT, Johnson ED, Plummer KM, Anderson MA: Inhibition of cereal rust fungi by both class I and II defensins derived from the flowers of Nicotiana alata. Mol Plant Pathol 2014, 15:67-79.

57. Kolar SS, Baidouri H, Hanlon S, McDermott AM: Protective role of murine $\beta$-defensins 3 and 4 and cathelin-related antimicrobial peptide in Fusarium solani keratitis. Infect Immun 2013, 81:2669-2677.

58. Sagaram US, Pandurangi R, Kaur J, Smith TJ, Shah DM: Structure-activity determinants in antifungal plant defensins MsDef1 and MtDef4 with different modes of action against Fusarium graminearum. PLOS ONE 2011, 6:e18550.

59. Rahnamaeian M: Antimicrobial peptides: modes of mechanism, modulation of defense responses. Plant Signal Behav 2011, 6(9):1325-1332.

60. Hynes WL, Ceraul SM, Todd SM, Seguin KC, Sonenshine DE: A defensin-like gene expressed in the black-legged tick. Ixodes scapularis. Med Vet Entomol 2005, 19(4):339-344.

doi:10.1186/s13071-014-0554-y

Cite this article as: Tonk et al.: Defensins from the tick Ixodes scapularis are effective against phytopathogenic fungi and the human bacterial pathogen Listeria grayi. Parasites \& Vectors 2014 7:554

\section{Submit your next manuscript to BioMed Central and take full advantage of:}

- Convenient online submission

- Thorough peer review

- No space constraints or color figure charges

- Immediate publication on acceptance

- Inclusion in PubMed, CAS, Scopus and Google Scholar

- Research which is freely available for redistribution 